\title{
The management of acid-base balance in children with diabetic acidosis
}

\author{
J. A. KUZEMKO \\ M.D., M.R.C.P.E., D.C.H., D.R.C.O.G. \\ Senior Paediatric Registrar
}

\author{
D. W. FIELDING \\ B.Sc., M.R.C.P., D.R.C.O.G. \\ Paediatric Registrar
}

\author{
F. P. HUdSON \\ F.R.C.P.E., D.C.H. \\ Consultant Paediatrician
}

Alder Hey Children's Hospital and Royal Liverpool Children's Hospital, Liverpool

\begin{abstract}
Summary
Acid-base changes in eleven diabetic children admitted to hospital with keto-acidosis are described. Six children required intravenous sodium bicarbonate to correct the metabolic acidosis. It is concluded that immediate use of bicarbonate in these children was efficient, rapid and safe.
\end{abstract}

\section{Introduction}

Metabolic acidosis is one of the many biochemical complications which occur in uncontrolled diabetes mellitus; it is one of the most serious, and it may lead to death (Joslin \& Wilson, 1950; Klein \& Laron, 1956; Larson, Sterky \& Christianson, 1961). Early recognition and treatment of severe keto-acidosis is of paramount importance if the patient is to survive.

We discuss this problem in eleven children with diabetic ketosis and the management of the more severe episodes with intravenous bicarbonate solution.

\section{Methods}

$\mathrm{PCO}_{2}, \mathrm{pH}$, standard bicarbonate and base deficits (in $\mathrm{mEq} / \mathrm{l}$ ) were determined by micro-Astrup apparatus (Astrup et al., 1960). Electrolytes, blood sugars and haematological values were performed by routine laboratory methods employing microtechniques.

Each child was weighed on admission and the bicarbonate dose (mEq) was calculated as recommended by Astrup et al. (1960) (base deficit $\times 0.3 \times$ body weight in $\mathrm{kg})$. Molar bicarbonate $(8.4 \% \mathrm{w} / \mathrm{v}$; $1 \mathrm{mEq} / \mathrm{ml}$ ) was used intravenously.

\section{Case reports}

\section{Case 1}

J.P., a 9-year-old girl, diagnosed as having diabetes mellitus in May 1966, remained well on
32 units Insulin Zinc Suspension (Lente) and a 'free' diet up to June 1967, when she developed an upper respiratory tract infection which did not improve over 2 weeks. She progressively deteriorated; 2 days before admission she complained of abdominal pains, started to vomit and rapidly became drowsy. Urine testing over $48 \mathrm{hr}$ preceding admission to hospital revealed heavy glycosuria and acetonuria.

On examination, she was unconscious and moderately dehydrated; the respirations were gasping and her breath smelled strongly of acetone. Axillary temperature $94^{\circ} \mathrm{F}$, weight $26 \mathrm{~kg}$. Extremities cold. Pulse was rapid and thready and blood pressure barely recordable. Pupils were equal and gave a sluggish reaction to light; fundi were normal. Examination was otherwise negative. No obvious focus of infection was detected.

Investigations: Urine-trace of albumin; glycosuria $4+$; acetone $3+$. Blood sugar $1250 \mathrm{mg} / 100 \mathrm{ml}$, sodium 126 , potassium $5 \cdot 5$, chloride $90 \mathrm{mEq} / 1$. urea $130 \mathrm{mg} / 100 \mathrm{ml}, \mathrm{Hb} 14.45 \mathrm{~g} / 100 \mathrm{ml}$, PCV $44 \%$, WBC $23,000 / \mathrm{mm}^{3}, 83 \%$ neutrophils, $17 \%$ lymphocytes.

Initial treatment consisted of normal saline, 50 units of soluble insulin and $100 \mathrm{mEq}$ of sodium bicarbonate intravenously. Penicillin and streptomycin were given by intramuscular injection. The response to bicarbonate therapy was extremely good and after $30 \mathrm{~min}$ she was semiconscious, although her blood sugar at the time was still $1300 \mathrm{mg} / 100 \mathrm{ml}$ and although only $300 \mathrm{ml}$ of normal saline were infused. Acid-base changes and blood sugar levels during the first $24 \mathrm{hr}$ are recorded in Table 1 .

In all she received 4 litres of normal saline and 160 units of soluble insulin during the first $24 \mathrm{hr}$. Further progress was uneventful and she was discharged home 14 days after admission on a 2000 calorie diet containing $200 \mathrm{~g}$ of carbohydrate and 40 units of Insulin Zinc Suspension (Iente) daily. 
TABLE 1. Biochemical changes and insulin given in Case 1

\begin{tabular}{|c|c|c|c|c|c|c|c|}
\hline Time & $\mathrm{pH}$ & $\begin{array}{c}\mathrm{PCO}_{2} \\
(\mathrm{mmHg})\end{array}$ & $\begin{array}{c}\text { Standard } \\
\text { bicarbonate } \\
(\mathrm{mEq} / \mathrm{l})\end{array}$ & $\begin{array}{c}\text { Base } \\
\text { deficit } \\
(\mathrm{mEq} / \mathrm{l})\end{array}$ & $\begin{array}{l}\text { Bicarbonate } \\
\text { given (mEq) }\end{array}$ & $\begin{array}{c}\text { Blood } \\
\text { sugar } \\
(\mathrm{mg} / 100 \mathrm{ml})\end{array}$ & $\begin{array}{l}\text { Soluble } \\
\text { insulin } \\
\text { units }\end{array}$ \\
\hline 10.30 hours & $7 \cdot 02$ & 23 & 8 & 27 & 100 & 1250 & 100 \\
\hline 11.00 hours & $7 \cdot 29$ & 11 & $11 \cdot 1$ & 20 & 50 & 1300 & \\
\hline 14.00 hours & $7 \cdot 30$ & 23 & $14 \cdot 5$ & $13 \cdot 5$ & 50 & 670 & 50 \\
\hline 17.00 hours & $7 \cdot 48$ & 16 & $19 \cdot 7$ & 6 & & & \\
\hline 22.00 hours & $7 \cdot 42$ & 25 & $21 \cdot 2$ & 4 & & 400 & 10 \\
\hline 21.00 hours & $7 \cdot 43$ & $32 \cdot 5$ & $22 \cdot 5$ & $1 \cdot 5$ & & 210 & \\
\hline
\end{tabular}

TABLE 2. Biochemical changes and insulin given in Case 2

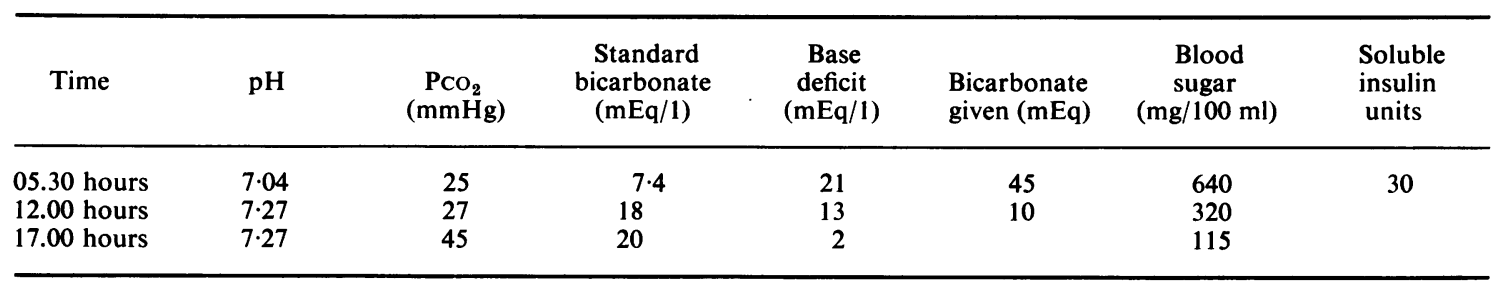

TABLE 3. Biochemical changes and insulin given in Case 3

\begin{tabular}{|c|c|c|c|c|c|c|c|c|}
\hline Time & $\mathrm{pH}$ & $\begin{array}{c}\mathrm{PCO}_{2} \\
(\mathrm{mmHg})\end{array}$ & $\begin{array}{c}\text { Standard } \\
\text { bicarbonate } \\
(\mathrm{mEq} / \mathrm{l})\end{array}$ & $\begin{array}{c}\text { Base } \\
\text { deficit } \\
(\mathrm{mEq} / \mathrm{l})\end{array}$ & $\begin{array}{l}\text { Bicarbonate } \\
\text { given }(\mathrm{mEq})\end{array}$ & $\begin{array}{c}\text { Blood } \\
\text { sugar } \\
(\mathrm{mg} / 100 \mathrm{ml})\end{array}$ & $\begin{array}{l}\text { Soluble } \\
\text { insulin } \\
\text { units }\end{array}$ & 음 \\
\hline 15.00 hours & $7 \cdot 12$ & 17 & $9 \cdot 8$ & 23 & & 765 & 50 & \\
\hline 19.00 hours & $7 \cdot 20$ & 20 & 14 & 17 & & 800 & 50 & \\
\hline 23.00 hours & $7 \cdot 25$ & 24 & 15 & $15 \cdot 5$ & 20 & 560 & 25 & \\
\hline 03.00 hours & & & & & & & 25 & \\
\hline 09.00 hours & $7 \cdot 40$ & 31 & 21 & $3 \cdot 5$ & & 128 & & \\
\hline 13.30 hours & $7 \cdot 35$ & 42 & $22 \cdot 5$ & 2 & & 153 & & \\
\hline
\end{tabular}

\section{Case 2}

A.McG. A 5-year-old boy was admitted to hospital in 1965 with vomiting of $24 \mathrm{hr}$ duration and polyuria and polydipsia of 3 days' duration. He was the second child of healthy parents; there was no family history of diabetes mellitus.

On examination he was moderately dehydrated and semi-conscious. Respirations were gasping, pulse $140 / \mathrm{min}$; BP $100 / 70$. His throat was inflamed. Weight, $15 \cdot 5 \mathrm{~kg}$.

Investigations : blood sugar $640 \mathrm{mg} / 100 \mathrm{ml}, \mathrm{Hb} 14$ $\mathrm{g} / 100 \mathrm{ml}$, WBC $21,000 / \mathrm{mm}^{3}(90 \%$ neutrophils, $10 \%$ lymphocytes). Blood urea $32 \mathrm{mg} / 100 \mathrm{ml}$, sodium 126 , potassium $3 \cdot 6$, chloride $100 \mathrm{mEq} / \mathrm{l}$. Acid-base changes and blood sugar levels are given in Table 2.

He was treated with normal saline and soluble insulin; sodium bicarbonate solution was given twice, on admission and $6 \mathrm{hr}$ later. There was rapid improvement following bicarbonate infusion. Further progress was satisfactory. He was discharged home on a 'free' diet and 14 units of Insulin Zinc Suspension (Lente) daily.

\section{Case 3}

R.B. An 8-year-old boy was admitted to hospital in July 1966 with a 3-day history of thirst, polyuria and glycosuria. No family history of diabetes mellitus.

On examination he was very dehydrated; pulse rapid; BP 80/50. No other abnormal findings. No focus of infection found. Weight $26 \mathrm{~kg}$.

Investigations: Blood sugar $765 \mathrm{mg} / 100 \mathrm{ml} . \mathrm{Hb}$ $13.5 \mathrm{~g} / 100 \mathrm{ml}, \mathrm{WBC} 16,000 / \mathrm{mm}^{3}(67 \%$ neutrophils, $21 \%$ lymphocytes, $2 \%$ monocytes). Urine: trace of protein, sugar $3+$, acetone $4+$. Sodium 138, potassium 2.1, chloride $101 \mathrm{mEq} / \mathrm{l}$. Blood urea $153 \mathrm{mg} / 100 \mathrm{ml}$. Acid-base changes and blood sugar levels are shown in Table 3. 
TABLE 4. Biochemical changes and insulin given in Case 4

\begin{tabular}{lllccccc}
\hline Time & $\mathrm{pH}$ & $\begin{array}{c}\mathrm{PCO}_{2} \\
(\mathrm{mmHg})\end{array}$ & $\begin{array}{c}\text { Standard } \\
\text { bicarbonate } \\
(\mathrm{mEq} / \mathrm{l})\end{array}$ & $\begin{array}{c}\text { Base } \\
\text { deficit } \\
(\mathrm{mEq} / \mathrm{l})\end{array}$ & $\begin{array}{c}\text { Bicarbonate } \\
\text { given }(\mathrm{mEq})\end{array}$ & $\begin{array}{c}\text { Blood } \\
\text { sugar } \\
(\mathrm{mg} / 100 \mathrm{ml})\end{array}$ & $\begin{array}{c}\text { Soluble } \\
\text { insulin } \\
\text { units }\end{array}$ \\
\hline 21.30 hours & $7 \cdot 12$ & 21 & $9 \cdot 5$ & 22 & 40 & 560 & 25 \\
24.00 hours & $7 \cdot 10$ & $18 \cdot 5$ & $8 \cdot 8$ & 23 & 40 & 225 & 16 \\
09.30 hours & $7 \cdot 29$ & 31 & 15 & $10 \cdot 5$ & & 142 \\
22.00 hours & $7 \cdot 51$ & $38 \cdot 5$ & 20 & $+7 \cdot 5$ & & 16 \\
\hline
\end{tabular}

TABLE 5. Biochemical changes and insulin given in Case 5

\begin{tabular}{|c|c|c|c|c|c|c|c|}
\hline Time & $\mathrm{pH}$ & $\begin{array}{c}\mathrm{PCO}_{2} \\
(\mathrm{mmHg})\end{array}$ & $\begin{array}{c}\text { Standard } \\
\text { bicarbonate } \\
(\mathrm{mEq} / \mathrm{l})\end{array}$ & $\begin{array}{c}\text { Base } \\
\text { deficit } \\
(\mathrm{mEq} / \mathrm{l})\end{array}$ & $\begin{array}{l}\text { Bicarbonate } \\
\text { given }(\mathrm{mEq})\end{array}$ & $\begin{array}{c}\text { Blood } \\
\text { sugar } \\
(\mathrm{mg} / 100 \mathrm{ml})\end{array}$ & $\begin{array}{c}\text { Soluble } \\
\text { insulin } \\
\text { units }\end{array}$ \\
\hline 17.00 hours & $7 \cdot 07$ & 12 & $7 \cdot 5$ & 24 & 50 & 750 & 50 \\
\hline 20.30 hours & $7 \cdot 31$ & 16 & 12 & $15 \cdot 5$ & 25 & 250 & \\
\hline 23.00 hours & $7 \cdot 44$ & 28 & 22 & $2 \cdot 5$ & & 108 & 14 \\
\hline 09.30 hours & $7 \cdot 44$ & 25 & +1.0 & & & 175 & \\
\hline
\end{tabular}

He was treated with normal saline, $500 \mathrm{ml}$ being given every $3 \mathrm{hr}$ with $1 \mathrm{~g}$ of potassium chloride in alternate $500 \mathrm{ml}$ bottles. One hundred and fifty units of soluble insulin were required to stabilize him during the first $24 \mathrm{hr}$ of treatment. Further progress: satisfactory. Discharged home on a free diet and 20 units Insulin Zinc Suspension (Lente) daily.

Comment: This child remained clinically acidotic for much longer than the children who were given sodium bicarbonate early, but once acidosis was partially corrected with intravenous bicarbonate his improvement was rapid. In this particular instance bicarbonate was given $8 \mathrm{hr}$ after admission.

\section{Case 4}

C.H. A 7-year-old boy admitted to hospital in 1965 with symptoms suggestive of diabetes mellitus. No family history of diabetes.

On examination, weight $20 \mathrm{~kg}$. Wasted and lethargic child. Sighing respirations. Pulse rate $120 /$ min. BP 120/70. Reflexes uniformly sluggish. Pupils and fundi normal.

Investigations: Urine-glucose $3+$, acetone $2+$, albumin $1+$. Blood sugar $560 \mathrm{mg} / 100 \mathrm{ml}$. Haemoglobin $13.9 \mathrm{~g} / 100 \mathrm{ml}$, WBC $16,000 / \mathrm{mm}^{3}(81 \%$ neutrophils, $19 \%$ lymphocytes). Blood urea 42 $\mathrm{mg} / 100 \mathrm{ml}$, sodium 112 , potassium 4.6 , chloride $98 \mathrm{mEq} / \mathrm{l}$. Acid-base changes and blood sugar levels are shown in Table 4.

He was treated with normal saline, soluble insulin (25 units initially) and sodium bicarbonate. His total base deficit was estimated at about $130 \mathrm{mEq}$ hence $40 \mathrm{mEq}$ of sodium bicarbonate were given on admission and repeated $2 \frac{1}{2} \mathrm{hr}$ later. Further progress was uneventful. He was discharged home on a 'free' diet and 20 units of Lente insulin daily.

\section{Case 5}

C.S. A 9-year-old boy originally diagnosed as having diabetes mellitus in 1961 at the age of 4 years. Progress satisfactory up to the end of 1966 when he required 18 units of Lente insulin daily. He was then admitted to hospital with a 24-hr history of polyuria, polydipsia, vomiting and drowsiness.

On examination, weight $28.2 \mathrm{~kg}$. He was drowsy, his respirations were gasping; there was some dehydration but no wasting. Pulse 110; systolic blood pressure $70 / \mathrm{mmHg}$. Bilateral otitis media was present.

Investigations: Blood sugar $750 \mathrm{mg} / 100 \mathrm{ml}, \mathrm{Hb}$ $14 \mathrm{~g} / 100 \mathrm{ml}$, WBC $35,000 / \mathrm{mm}^{3}$ (neutrophils $74 \%$, lymphocytes $36 \%$ ), blood urea $80 \mathrm{mg} / 100 \mathrm{ml}$; sodium 136, potassium 5.5 , chloride $100 \mathrm{mEq} / \mathrm{l}$. Acid-base changes and blood sugar levels are shown in Table 5. He was given normal saline and $50 \mathrm{mEq}$ of sodium bicarbonate on admission and $25 \mathrm{mEq}$ were given 3! hr later before his acid-base changes reverted to normal. Again it was noted that there was rapid improvement in his clinical state with correction of metabolic acidosis. Subsequent progress was uneventful and he was discharged home on Lente insulin 20 units daily and a 'free' diet. 
TABLE 6. Biochemical changes and insulin given in Case 6

\begin{tabular}{|c|c|c|c|c|c|c|c|}
\hline Time & $\mathrm{pH}$ & $\underset{(\mathrm{mmHg})}{\mathrm{PcO}_{2}}$ & $\begin{array}{l}\text { Standard } \\
\text { bicarbonate } \\
(\mathrm{mEq} / \mathrm{l})\end{array}$ & $\begin{array}{c}\text { Base } \\
\text { deficit } \\
(\mathrm{mEq} / \mathrm{l})\end{array}$ & $\begin{array}{l}\text { Bicarbonate } \\
\text { given (mEq) }\end{array}$ & $\begin{array}{c}\text { Blood } \\
\text { sugar } \\
(\mathrm{mg} / 100 \mathrm{ml})\end{array}$ & $\begin{array}{l}\text { Soluble } \\
\text { insulin } \\
\text { units }\end{array}$ \\
\hline \multicolumn{7}{|l|}{ (a) First day } & 68 (Lente) \\
\hline 12.00 hours & 6.9 & 20 & 6 & $>22$ & 200 & 346 & \\
\hline 14.00 hours & $7 \cdot 15$ & 21 & 10 & $20 \cdot 5$ & 200 & 570 & 16 (soluble) \\
\hline 16.30 hours & $7 \cdot 28$ & 34 & 16 & $9 \cdot 5$ & 150 & 640 & 16 (soluble) \\
\hline \multicolumn{8}{|l|}{ (b) Second day } \\
\hline 06.30 hours & & & & & & & 72 (Lente) \\
\hline 11.30 hours & 6.9 & 19 & 6 & $>22$ & 300 & 510 & \\
\hline 14.30 hours & $7 \cdot 16$ & 20 & 10 & 21 & 250 & 460 & 16 (soluble) \\
\hline
\end{tabular}

\section{Case 6}

J.O. A 10-year-old girl diagnosed as having diabetes mellitus in October 1966 and initially stabilized on 68 units Lente insulin and a diet containing $200 \mathrm{~g}$ carbohydrate each day. She was admitted to hospital seven times in the next 12 months with ketosis resulting from dietary indiscretions, minor infections or emotional disturbances. In December 1967 she was again admitted with sore throat, nausea, vomiting and abdominal pain.

On examination there was little to find except mild dehydration; her weight was $30 \mathrm{~kg}$. She was afebrile and there was no obvious source of infection, nor any hyperpnoea. The urine showed heavy glycosuria and acetonuria. Pulse, blood pressure and peripheral circulation were normal.

Investigations: Blood sugar $400 \mathrm{mg} / 100 \mathrm{ml}$; sodium 131 , potassium $4 \cdot 5$, chloride 103 , alkali reserve $10.5 \mathrm{mEq} / \mathrm{l}$, urea $25 \mathrm{mg} / 100 \mathrm{ml}, \mathrm{Hb} 14 \mathrm{~g} /$ $100 \mathrm{ml}$, WBC $10,000 / \mathrm{mm}^{3}$. Throat swab-no pathogens; urine-no evidence of infection.

Treatment consisted of intravenous normal saline $1000 \mathrm{ml}$ followed by $500 \mathrm{ml} \mathrm{N} / 2$ saline with $5 \%$ dextrose. No additional insulin was given on the day of admission, nor any sodium bicarbonate. Within $3 \mathrm{hr}$ of starting intravenous therapy the blood sugar fell to $140 \mathrm{mg} / 100 \mathrm{ml}$, nausea and vomiting had subsided and she was sitting up in bed asking for food and drink. Intravenous therapy was, therefore, discontinued, although the urine still showed glycosuria and moderate acetonuria.

The following morning profuse vomiting recurred followed by dehydration, hyperpnoea and minimal peripheral circulatory failure. She had been given her normal dose of Lente insulin earlier because of the apparent recovery the previous day. Clinically she was drowsy, pulse rate $140 / \mathrm{min}$, BP $85 / 60$, tongue brown and dry.

Investigations: Urea $25 \mathrm{mg} / 100 \mathrm{ml}$; sodium 131 , potassium $4 \cdot 8$, chloride 102 , alkali reserve $3 \mathrm{mEq} / \mathrm{l}$.
Acid-base balance and blood sugar levels are shown in Table 6(a).

Intravenous therapy was restarted and ampicillin $\mathrm{i}$ commenced. $200 \mathrm{ml}$ of $8.4 \%$ sodium bicarbonate $\vec{\circ}$ were given rapidly and followed by a marked im- $\supset$ provement in pulse, blood pressure, peripheral cir- $\vec{c}$ culation and respirations. Intravenous therapy was continued with normal saline.

Two hours later there was further improvement, blood sugar and acid-base findings as in Table 6(a\$ $\overrightarrow{0}$ Soluble insulin (16 units) was given and a furthe of $200 \mathrm{ml} 8.4 \%$ sodium bicarbonate, followed in further $2 \mathrm{hr}$ by $150 \mathrm{ml}$, and in a further $2 \mathrm{hr}$ by 150 $\mathrm{ml}$ and more soluble insulin (16 units). Improvement again quickly followed the administration of bicarbonate.

On the 3rd day her general condition was good $\stackrel{\mathbb{\Omega}}{\rightleftharpoons}$ although the blood sugar was still high (490, 250 and $\frac{O}{3}$ $270 \mathrm{mg} / 100 \mathrm{ml}$ ). Other investigations: sodium 145 , chloride 115 , potassium $3 \cdot 3$, alkali reserve $23 \mathrm{mEq} / \mathrm{l}$, urea $22 \mathrm{mg} / 100 \mathrm{ml}$. Nausea and vomiting were no longer a feature of the illness, she was drinking well $\frac{}{3}$ and acetonuria was decreasing. Twenty-four hours later the improvement had been maintained and all 3 . therapy, except Lente insulin (72 units) and ampicillin was discontinued.

She remained well for 2 days then again relapsed, 응 the same clinical and biochemical events recurring, i.e. acetonuria, nausea, vomiting, drowsiness and $\frac{7}{0}$ peripheral circulatory failure. Acid-base changes were as severe as before and are summarized in $\sigma$ Table 6(b).

Similar therapy was given. A total of $550 \mathrm{ml} N$ $8.4 \%$ sodium bicarbonate was again required before the acid-base balance approximated to normal. Rapid improvement occurred and within $18 \mathrm{hr} \stackrel{\odot}{\odot}$ biochemical and clinical states were excellent. $\stackrel{\oplus}{\rightarrow}$ (Blood sugars 225 and $175 \mathrm{mg} / 100 \mathrm{ml}$.)

A stable diabetic condition is now maintained with a mixture of protamine zinc and soluble 
TABLE 7. Biochemical state of patients not requiring bicarbonate

\begin{tabular}{cccccc}
\hline Case No. & $\mathrm{pH}$ & $\begin{array}{c}\mathrm{Pco}_{2} \\
(\mathrm{mmHg})\end{array}$ & $\begin{array}{c}\text { Standard } \\
\text { bicarbonate } \\
(\mathrm{mEq} / \mathrm{l})\end{array}$ & $\begin{array}{c}\text { Base } \\
\text { deficit } \\
(\mathrm{mEq} / \mathrm{l})\end{array}$ & $\begin{array}{c}\text { Blood } \\
\text { sugar } \\
(\mathrm{mg} / 100 \mathrm{ml})\end{array}$ \\
\hline 7 & $7 \cdot 35$ & 31 & $20 \cdot 5$ & 1 & 500 \\
8 & $7 \cdot 35$ & 18 & $17 \cdot 5$ & 10 & 325 \\
9 & $7 \cdot 34$ & 35 & $19 \cdot 5$ & 6 & 720 \\
10 & $7 \cdot 22$ & 34 & $14 \cdot 5$ & 7 & 575 \\
11 after $24 \mathrm{hr}$ & $7 \cdot 34$ & 24 & 16 & 11 & 500 \\
& $7 \cdot 34$ & 41 & $20 \cdot 5$ & 3 & 260 \\
\hline
\end{tabular}

TABLE 8. Biochemical state of patients requiring bicarbonate

\begin{tabular}{lccccc}
\hline Case No. & $\mathrm{pH}$ & $\begin{array}{c}\mathrm{Pco}_{2} \\
(\mathrm{mmHg})\end{array}$ & $\begin{array}{c}\text { Standard } \\
\text { bicarbonate } \\
(\mathrm{mEq} / \mathrm{l})\end{array}$ & $\begin{array}{c}\text { Base } \\
\text { deficit } \\
(\mathrm{mEq} / \mathrm{l})\end{array}$ & $\begin{array}{c}\text { Blood } \\
\text { sugar } \\
(\mathrm{mg} / 100 \mathrm{ml})\end{array}$ \\
\hline 1. J.P. & 7.02 & 23 & 8 & 27 & 1,250 \\
2. A.McG. & $7 \cdot 04$ & 25 & $7 \cdot 4$ & 21 & 640 \\
3. R.B. & $7 \cdot 12$ & 17 & $9 \cdot 8$ & 23 & 765 \\
4. L.H. & $7 \cdot 12$ & 21 & $9 \cdot 5$ & 22 & 560 \\
5. C.S. & $7 \cdot 07$ & 12 & $7 \cdot 5$ & 24 & 750 \\
6. J.O. & 6.9 & 20 & 6 & $>22$ & 346 \\
(a) & 6.9 & 19 & 6 & $>22$ & 510 \\
(b) & & & & & \\
\hline
\end{tabular}

insulins (36 and 32 units, respectively) combined with a diet containing $220 \mathrm{~g}$ carbohydrate/day.

Five other children were admitted to hospital with diabetic keto-acidosis, but in these the metabolic acidosis was not severe enough to require correction with sodium bicarbonate. The initial acid-base state and blood sugar levels are summarized in Table 7.

\section{Discussion}

Although most children with diabetic keto-acidosis will respond well when fluid and electrolyte losses are replaced and insulin given, there are some who need rapid correction of the metabolic acidosis. Few patients survive prolonged depression of the blood pH below 7.0 (Siggaard-Anderson, 1963). Thrower, Darby \& Aldinger (1961) showed that if acidosis persists a stage may be reached when death will ensue despite correction of the underlying metabolic disturbance. Enzyme activity may be impaired by a drop in pH (Barness, 1959). Addis, Thomson \& Welch (1964) accept a pH of 7.2 as the lowest 'safe' level in an adult diabetic.

It is desirable to correct rapidly, even though only partially, the metabolic acidosis present in diabetic ketosis. For many years a $M / 6$ solution of sodium lactate has been used for this purpose, and this treatment is still recommended in some textbooks.
Unfortunately some diabetics when ketotic have a high blood lactate level (Walker, Linton \& Thomson, 1960; Anderson, Thomas \& Tomlinson, 1966), and furthermore oxygen may not be readily available for conversion of lactate to bicarbonate which is the chief buffer of plasma. For efficient and safe administration of intravenous sodium bicarbonate use must be made of the Astrup apparatus for rapid estimations of $\mathrm{pH}$ and $\mathrm{PCO}_{2}$ and calculation of the base deficit (Astrup et al., 1960). The technique is not difficult to learn and the test may sometimes be regarded as a bedside rather than a laboratory procedure. In the first instance the calculation of bicarbonate required should aim at half or threequarter correction in order to prevent a secondary alkalosis. The intention is to help the natural processes of repair and to avoid over-correction.

Case 6 was probably in greater danger than the others as shown by the blood $\mathrm{pH}$ and base deficit. Estimation of blood sugar in her case gave little help in planning treatment and indeed the blood sugar rose while the base deficit fell and while her clinical state improved (Table 6a).

Some of the initial biochemical estimations in the six children who received sodium bicarbonate are shown in Table 8. According to the criteria of Addis et al. (1964) the pH of all was at a dangerously low level. Tables 1-6 show the rapid correction in $\mathrm{pH}$ obtained. Excellent clinical improvement always 
followed even when the blood sugar level remained high. This feature has been commented on by others (Phear, 1963; Cunningham \& Hilton, 1964; Addis et al., 1964). It is probable that with this treatment the insulin requirement will sometimes be lower than with other regimens, and it becomes even more essential to watch for evidence of dangerous hypoglycaemia during the stage of recovery.

\section{Acknowledgments}

We wish to thank Professor J. D. Hay, Dr R. W. Brookfield and Dr J. R. Roberts for permission to study some of the patients admitted under their care.

\section{References}

Addis, G.J., Thomson, W.S.T. \& Welch, J.D. (1964) Bicarbonate therapy in diabetic acidosis. Lancet, ii, 223.

Anderson, J., Thomas, W.D. \& Tomlinson, R W.S. (1966) Pyruvate and lactate excretion in diabetes mellitus after sodium lactate. Brit. med. J. ii, 1114.

Astrup, P., Jorgensen, K., Andersen, O.S. \& Engel, K. (1960) The acid-base metabolism; a new approach. Lancet, i, 1035.
Barness, L.A. (1959) Symposium on fluid and electrolyte problems. Pediat. Clin. N. Amer. 6, 25.

Cunningham, J.S. \& Hilton, P.J. (1964) Bicarbonate therapy in diabetic acidosis (letter). Lancet, ii, 758.

JosLiN, E.P. \& WiLson, J.L. (1950) Lessons for future treat- $\overrightarrow{\bar{\omega}}$ ment from 472 fatalities in diabetic children. Brit. med. J. ii, 1293.

Klein, R. \& LARON, F. (1956) Current problems in diabetes. Pediatrics, 18, 983.

Larson, Y., Sterky, G. \& Christianson, G. (1961) Longterm prognosis in juvenile diabetes mellitus. Acta paediat. ڤ్ scand. 51, Suppl. 130, 29.

Phear, D.N. (1963) Effects of acidosis. Conference on diabetes. Brit. med. J. ii, 1581.

SiggaARd-ANDERSON, O. (1963) The acid-base status of the blood. Scand. J. clin. Invest. 15, Suppl. 70, 28.

Thrower, W.B., Darby, T.D. \& Aldinger, E.E. (1961) Acid-base derangements and myocardial contractibility. Arch. Surg. 82, 56.

Walker, R.S., Linton, A.L. \& Thomson, W.S.T. (1960) Mode of action and side-effects of phenformin hydrochloride. Brit. med. J. ii, 1567. 